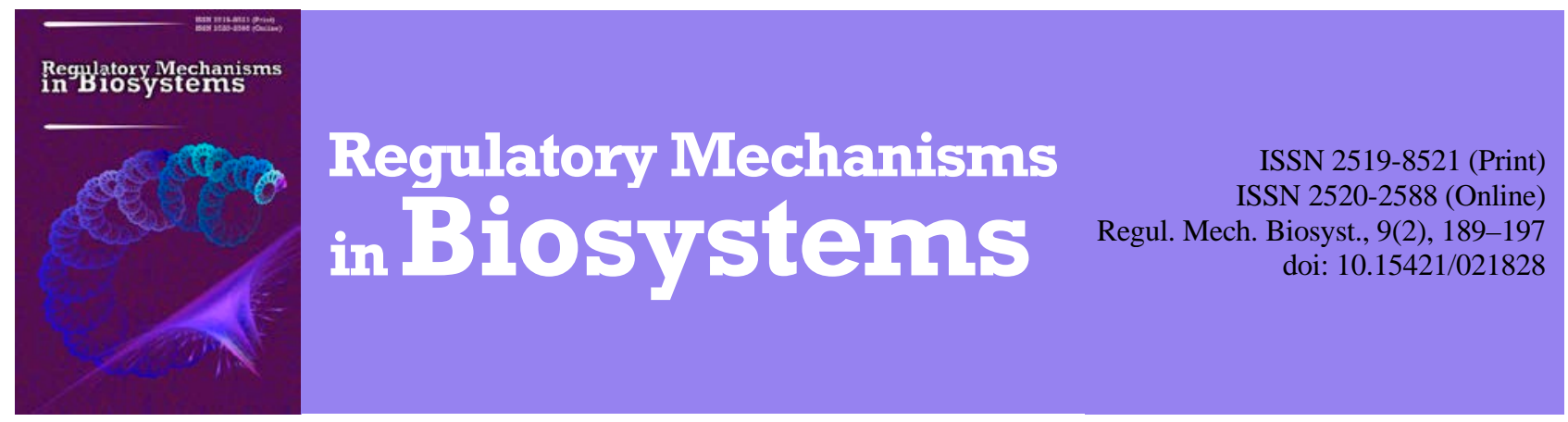

\title{
Cytogenetic activity of radionuclide contamination of water reservoirs of the alienation zone of Chornobyl NPP
}

\author{
R. A. Yakymchuk \\ Institute of Plant Physiology and Genetics of NAS of Ukraine, Kyiv, Ukraine
}

Article info

Received 04.03.2018

Received in revised form 11.04.2018

Accepted 12.04.2018

Institute of Plant Physiology and Genetics of NAS of Ukraine, Vasylkivska st., 31/17,

Kyiv, 03022, Ukraine

Tel.: +38-097-341-89-12.

E-mail:

peoplenature16@gmail.com
Yakymchuk, R. A. (2018). Cytogenetic activity of radionuclide contamination of water reservoirs of the alienation zone of Chornobyl NPP. Regulatory Mechanisms in Biosystems, 9(2), 189-197. doi:10.15421/021828

Thirty years after the accident, the alienation zone of Chornobyl NPP continues to be an open source of radionuclide spread which is carried with superficial and soil waters into river systems and moves beyond the area. The study of mutagenic activity of radionuclide contamination of the water reservoirs in the near zone of Chornobyl NNP will make it possible to predict genetic consequences of their effect in the years after the accident. The purpose of this research is to study frequency and spectrum of chromosome aberrations in root meristem cells of Triticum aestivum L. under the prolonged effect of radionuclide contamination of water and bottom deposits of the water reservoirs in the near alienation zone of Chornobyl NPP. Seeds of winter wheat varieties Al'batros odes'kyi and Zymoiarka were sprouted in the conditions of the effect of water radionuclide contamination of the Prypiat River, Brahinka River, a reservoir-cooler of ChNPP, Semyhodskyi backwater, drainage-way 3 of ChNPP, Lakes Hlyboke and Azbuchyn (total specific activity of ${ }^{137} \mathrm{Cs}$ and ${ }^{90} \mathrm{Sr}$ - 0.17-52.99 $\mathrm{Bq} / \mathrm{M}^{3}$ ) and bottom deposits of the left and right banks of Prypiat canal, a reservoir-cooler of ChNPP, drainage-ways $1-3$ of ChNPP (total specific activity of ${ }^{137} \mathrm{Cs}$ and ${ }^{90} \mathrm{Sr}-16.0-45.0 \mathrm{~Bq} / \mathrm{kg}$ ). Frequency and spectrum of cytogenetic disorders were identified in the cells of root meristem sprouts with help of the ana-telophase method. Under the influence of radiation on water and bottom deposits of the water reservoirs in the alienation zone of ChNPP, a 1.6-4.2 times increase in the frequency of chromosome aberrations and mitosis disorders was found. The highest levels of cytogenetic activity were shown by water radionuclide contamination in a reservoir-cooler of ChNPP, Semyhodskyi backwater and bottom deposits of drainage-way 2 . The correlation between frequency of chromosome aberrations and specific value of radionuclide activity of water reservoirs has not been recorded, which can prove the induction of cytogenetic disorders resulting from the radiation in the low-rate range. The spectrum of cytogenetic disorder types is mostly represented by acentric fragments, bridges and lagging chromosomes. The induction of the cells with lagging chromosomes, which exhibit the highest levels (0.24-0.38\%), under the effect of radionuclide contamination of water in Hlyboke Lake, the Brahinka River, the Prypiat River, a reservoir-cooler of ChNPP and bottom deposits of drainage-way 3, allows one to assume the availability of aneugenic factors in the water reservoirs in the alienation zone of ChNPP. The water entities of the alienation zone of ChNPP, the level of radionuclide contamination of which is characterized by a high cytogenetic activity, induce cells with complex chromosome rearrangements of high frequency. Despite the decrease in chromosome aberration frequency effected by the water of the Prypiat River near Chornobyl city, the Brahinka River and bottom deposits of the right bank of Prypiat canal, the increased level of aneugenic cells and the induction of multiple chromosome rearrangements confirm the persistence of mutagenic activity in the abovementioned contaminated water entities.

\section{Цитогенетична активність радіонуклідних забруднень водойм зони відчуження Чорнобильської АЕС}

\author{
Р. А. Якимчук
}

Інститут фізіологї̈ рослин і генетики НАН Украӥни, Київ, Україна

Зона відчуження Чорнобильської АЕС через 30 років після аварії продовжує залишатись відкритим джерелом поширення радіонуклідів, що надходять із поверхневими та грунтовими водами в річкові системи та виносяться за ії межі. Вивчення мутагенної активності радіонуклідних забруднень водойм ближньої зони ЧАЕС дасть змогу встановити потенційну мутагенну небезпеку водних об’єктів і спрогнозувати генетичні наслідки їх впливу у віддалені строки після аварії. Мета досліджень - вивчити частоту та спектр хромосомних аберацій у клітинах кореневої меристеми Triticum aestivum L. за пролонгованої дії радіонуклідних забруднень води та донних відкладів водойм ближньої зони відчуження Чорнобильської АЕС. Насіння озимої пшениці сортів Альбатрос одеський і Зимоярка пророщували в умовах впливу радіонуклідних забруднень води р. Прип'ять, р. Брагінка, водойми-охолодника ЧАЕС, Семиходського затону, відвідного каналу 3 ЧАЕС, оз. Глибоке, оз. Азбучин (сумарна питома активність ${ }^{137} \mathrm{Cs} \mathrm{i}$ i $\mathrm{Sr}-0,17-52,99$ кБк/ $\mathrm{m}^{3}$ ), донних відкладів лівого та правого 
берегів Прип'ятського каналу, водойми-охолодника ЧАЕС, відвідних каналів 1-3 ЧАЕС (сумарна питома активність ${ }^{137} \mathrm{Cs}$ i ${ }^{90} \mathrm{Sr}-16,0-$ 45,0 кБк/кг). У клітинах кореневої меристеми проростків за допомогою ана-телофазного методу визначали частоту та спектр цитогенетичних порушень. За радіаційного впливу води та донних відкладів водойм зони відчуження ЧАЕС виявлено зростання частоти хромосомних аберацій і порушень мітозу в 1,6-4,2 раза. Найвищі рівні цитогенетичної активності виявили радіонуклідні забруднення води водоймиохолодника ЧАЕС, Семиходського затону та донних відкладів відвідного каналу 2. Залежності між частотою хромосомних аберацій та величиною питомої активності радіонуклідів водойм не виявлено, що можна пояснити індукуванням цитогенетичних порушень унаслідок опромінення в діапазоні низьких доз. Спектр їх типів переважно представлений ацентричними фрагментами, мостами та відстаючими хромосомами. Індукування клітин із відстаючими хромосомами, що виявляють найвищі рівні $(0,24-0,38 \%)$ за дії радіонуклідних забруднень води оз. Глибоке, р. Брагінка, р. Прип'ять, водойми-охолодника ЧАЕС і донних відкладів відвідного каналу 3 дозволяе припустити наявність у водоймах зони відчуження ЧАЕС анеугенних чинників. Водні об'єкти зони відчуження ЧАЕС, рівень радіонуклідних забруднень яких характеризується високою цитогенетичною активністю, індукують із високою частотою клітини 3 комплексними хромосомними перебудовами. Незважаючи на зниження частоти хромосомних аберацій за впливу води р. Прип'ять поблизу м. Чонобиль, р. Брагінка та донних відкладів правого берега Прип'ятського каналу, підвищений рівень анеугенних клітин та індукування множинних хромосомних перебудов свідчить про збереження мутагенної активності забруднень зазначених водних об'єктів.

Ключові слова: Triticum aestivum L.; хромосомні аберації; порушення мітозу; мутагенна активність; генетичні наслідки

\section{Вступ}

Через 30 років після Чорнобильської катастрофи зона відчуження продовжує залишатись відкритим джерелом поширення радіонуклідів, що надходять із поверхневими та грунтовими водами в річкові системи та виносяться за іiі межі (Beresford et al., 2016; Evangeliou et al., 2016; Konoplev et al., 2016). Водойми басейнів Дніпра та Прип'яті - одні з найбільших водних систем у Європі зосередили близько 2,3 пБк ${ }^{90} \mathrm{Sr}$ i 19,6 пБк ${ }^{137} \mathrm{Cs}$ (Romanenko et al., 2014; Evangeliou et al., 2015). Більшість радіонуклідів, що потрапили до водойм, досить швидко акумулювалась донними відкладами. Зважаючи на те, що переважно у верхньому шарі донних відкладів депоновано ${ }^{90} \mathrm{Sr}-89-95 \%,{ }^{137} \mathrm{Cs}-99 \%,{ }^{238} \mathrm{Pu},{ }^{239+240} \mathrm{Pu}$, ${ }^{241} \mathrm{Am}$ - майже $100 \%$ загальної кількості радіонуклідів екосистеми (Gudkov et al., 2010; Ashraf et al., 2014; Bondar et al., 2015), питому радіоактивність водойм і водотоків нині визначає інтенсивність їх обміну з водними масами (Bondarkov et al., 2011; Gudkov et al., 2016a, 2016b). Серед найнебезпечніших наслідків радіонуклідного забруднення навколишнього середовища, викликаних аварією на Чорнобильській AEC, стали генетичні зміни організмів, які виявляються різними формами патогенезу, затриманням розвитку, росту, зниженням інтелекту, скороченням тривалості життя та загибеллю особин (Garnier-Laplace et al., 2015; Busby, 2017; Nakamura, 2018). Тому проведення досліджень мутагенної активності радіонуклідних забруднень води та донних відкладів водойм зони відчуження ЧАЕС дасть змогу встановити потенційну мутагенну небезпеку водних об'єктів, спрогнозувати масштабність генетичних наслідків неконтрольованого зниження рівня води у водоймах зони відчуження ЧАЕС, спричиненого природними кліматичними змінами та передбаченими інженерними контрзаходами з дезактиваціï (Talerko et al., 2013).

Iз часу аварії донині серед широкого кола науковців тривають дискусії навколо питання мутагенної активності низьких доз пролонгованого та хронічного опромінення та генетичних наслідків їх впливу в комплексі з хімічними антропогенними чинниками навколишнього середовища. У його вирішення значний внесок здійснили численні дослідження, проведені у природних умовах суходолу радіонуклідно забрудненої зони відчуження ЧАЕС, або ж у лабораторних умовах із використанням відібраних грунтових проб (Medvedeva et al., 2014; Mousseau \& Møller, 2014; Boubriak et al., 2016; Itoh et al., 2018). Проте вивченню генетичних наслідків радіонуклідних забруднень поверхневих вод, радіоекологічна ситуація в яких визначається кількістю осілих на водну поверхню радіоактивних речовин і складним комплексом тривалих взаємодій дотичних природних середовищ (Gudkov et al., 2010; Pohrebennyk et al., 2016), приділяється неналежна увага. У результаті низки гідробіологічних досліджень зони відчуження ЧАЕС (Sazykina \& Kryshev, 2003; Bondarkov et al., 2011; Gudkov et al., 2011; Fuller et al., 2015; Beresford et al., 2016; Gudkov et al., 2016; Shuryak, 2017) виявлено високий рівень аберацій хромосом в ембріональних тканинах риб, молюсків і кореневих меристемах вищих водних рослин, нехарактерне патологічне галуження пагонів очерету, аномальні новоутворення в місцях суцвіть, флуктуючу асиметрію стулок черепашки молюсків, аномалії в системі репродукції та ор- ганів риб, канцерогенез тварин, зниження стійкості до шкідників і хвороб, підвищення смертності. Переважно мутації в гідробіонтів індуковані хронічною дією інкорпорованих $\alpha$ - та $\beta$-випромінюючих радіонуклідів, які, локалізуючись у клітинному ядрі та комплексах ДНК-білок, зумовлюють високу відносну біологічну ефективність внутрішнього опромінення. Роль частки зовнішнього $\gamma$-опромінення у формуванні сумарної мутагенності водойм у віддалені строки після аварії на ЧАЕС залишається не достатньо дослідженою.

Найбілыш інформативні та чутливі маркери мутагенного забруднення (зокрема, хронічного радіаційного впливу в низьких дозах) - цитогенетичні показники, а саме хромосомні аберації в клітинах рослин (Al-Dulaimi et al., 2017; Qureshi et al., 2017). Розрахунки, виконані на основі вивчення наслідків опромінення, показали, що ймовірність виявлення аберацій хромосом у $10^{3}-10^{4}$ разів вища, ніж імовірність виявлення мутації окремого локусу, а оцінка мутаційного процесу за допомогою цитогенетичного аналізу дає результати, зіставні з результатами, отриманими методом електрофоретичного аналізу ізоферментів (Ramzaev et al., 2008). У зв'язку зі значним радіонуклідним забрудненням земель після аварії на Чорнобильській AEC особливої актуальності набуло вивчення впливу іонізуючого випромінювання на сільськогосподарські культури, зокрема, на озиму пшеницю (Kosakovskaja \& Gudkova, 2005), що зумовило iï широке використання як рослинного тестоб'єкта. Мета цієї статті - оцінити частоту та спектр хромосомних аберацій у клітинах кореневої меристеми Triticum aestivum L. за пролонгованої дії радіонуклідних забруднень води та донних відкладів водойм ближньої зони відчуження Чорнобильської АЕС.

\section{Матеріал і методи досліджень}

Насіння двох сортів пшениці м'якої озимої (Triticum aestivum L.) Альбатрос одеський і Зимоярка витримували впродовж 18 годин у пробах води р. Прип'ять (м. Чорнобиль), р. Брагінка (дамба 39), водойми-охолодника ЧАЕС (берегова насосна станція (БНС)), Семиходського затону, відвідного каналу 3 ЧАЕС, оз. Глибоке та оз. Азбучин (рис. 1), сумарна питома активність ${ }^{137} \mathrm{Cs} \mathrm{i}{ }^{90} \mathrm{Sr}$ в яких становила, відповідно, 0,17, 2,53, 2,11, 7,76, 91,99, 70,08 та 52,99 кБк/м³. Подальше пророщування насіння проводили за температури $24-26^{\circ} \mathrm{C}$ у чашках Петрі на зволоженому фільтрувальному папері. Для визначення цитогенетичної активності радіонуклідних забруднень донних відкладів водойм насіння пророщували протягом 40 годин у піщаних субстратах, відібраних на лівому та правому берегах Прип'ятського каналу (МК-6 поблизу мосту), у водоймі-охолоджувачі ЧАЕС (БНС), відвідних каналах 1-3 ЧАЕС, сумарна питома активність ${ }^{137} \mathrm{Cs} \mathrm{i}{ }^{90} \mathrm{Sr}$ в яких становила, відповідно, 23,2, 16,0, 26,7, 42,0, 45,0 та 17,0 кБк/кт. За контроль взято проби води та донних відкладів з умовно чистого оз. Голосіївське м. Київ, питома активність ${ }^{137} \mathrm{Cs}{ }^{90} \mathrm{Sr}$ в якому становила 0,021 кБк/м. $\mathrm{M}^{3}$. Проби води та донних відкладів відбирали в 2015 році за стандартними методиками (Parshad \& Sanford, 2001). Вимірювання питомої активності ${ }^{137} \mathrm{Cs} \mathrm{i}{ }^{90} \mathrm{Sr}$ проведено ДСП «Чорнобильський спецкомбінат» за допомогою $\gamma$-спектрометричного комплексу та низькофонового $\beta$-радіометра.

Корінці проростків довжиною 0,8-1,0 см протягом 4 годин фіксували у фіксаторі Кларка, що складається з 96\% розчину ети- 
лового спирту та льодяної оцтової кислоти у співвідношенні $3: 1$. Хімічну мацерацію корінців проводили в 1 н розчині соляної кислоти протягом 1 хв. Після закінчення мацерації 3 метою подальшого проведення аналізу хромосомних аберацій і порушень мітозу клітин корінці поміщали у розчин ацетоорсеїну на 24 години за температури $25^{\circ} \mathrm{C}$.

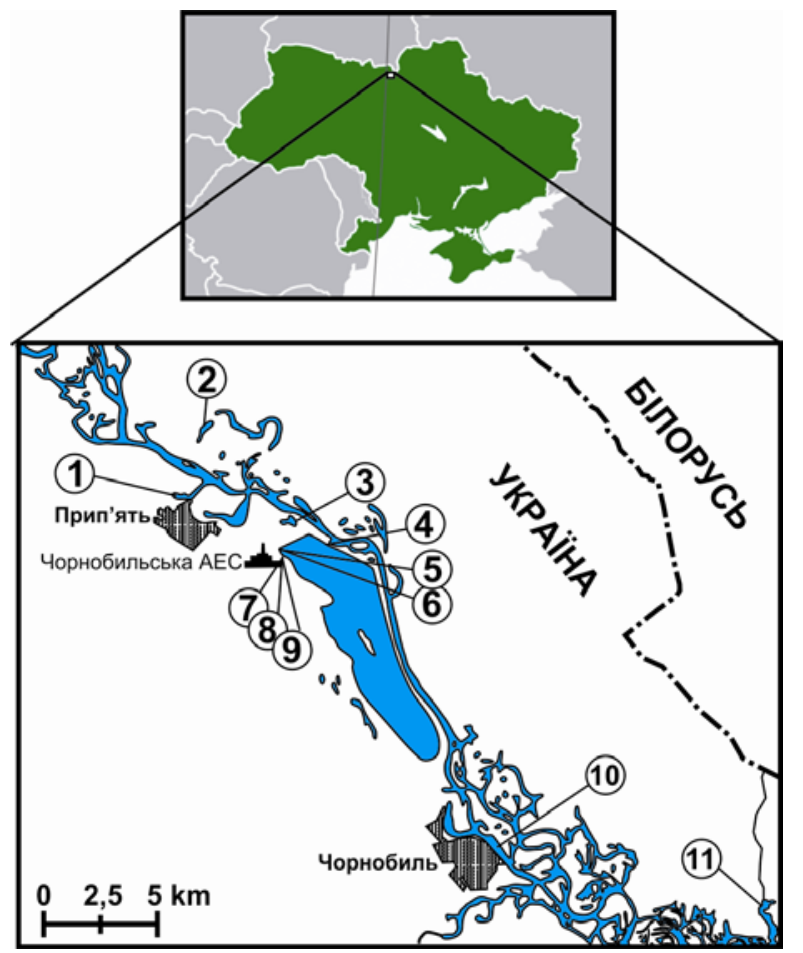

Рис. 1. Місця відбирання проб води та донних відкладів у зоні відчуження Чорнобильської АЕС: 1 - Семиходський затон,

2 - оз. Глибоке, 3 - оз. Азбучин, 4 - водойма-охолодник ЧАЕС (БНС), 5, 6 - лівий і правий берег Прип'ятського каналу

(МК-6 біля мосту), 7, 8, 9-відвідні канали 1-3 ЧАЕС, 10 - р. Прип'ять (м. Чорнобиль), 11 - р. Брагінка (дамба 39)

Для мікроскопічного аналізу готували тимчасові давлені цитологічні препарати за загальноприйнятими методиками (Pausheva, 1988). Мікроскопічне вивчення меристематичної зони корінців проводили із застосуванням мікроскопа Jenaval (Carl Zeiss, Jena) за збільшення ${ }^{\times} 900$. Під час визначення частоти хромосомних аберацій і порушень мітозу до уваги брали клітини, які перебували в анафазі та ранній телофазі. Вибірка для кожного варіанта становила не менше як 1000 клітин, які аналізували в $20 \mathrm{i}$ більше первинних корінцях. Ураховували частоту аберантних клітин як відсоток клітин в анафазі та ранній телофазі, що містили порушення хромосом. Для обчислення середньої кількості аберацій на аберантну клітину враховували клітини 3 0, 1, 2 та множинними хромосомними абераціями (>2 аберацій). Статистичну обробку експериментальних даних здійснювали загальноприйнятими методами, достовірність різниці оцінювали за критерієм Стьюдента після перевірки нормальності розподілу вибірки. У таблицях наведено відсоткові частки хромосомних аберацій та середні похибки вибіркових середніх арифметичних.

\section{Результати}

У меристематичних клітинах первинних корінців проростків пшениці, які зазнали радіаційного впливу водойм і водотоків зони відчуження ЧАЕС, виявлено зростання частоти хромосомних аберацій і порушень мітозу в 1,6-4,2 раза. Найвищий рівень цитогенетичної активності характерний для зразків води, відібраних із водойми-охолодника ЧАЕС та Семиходського затону. Частота хромосомних аберацій у 2,8-4,2 раза перевищувала показники контрольного рівня та складала 1,77\% і 1,90\% в меристематичних клітинах корінців сорту Альбатрос одеський і 2,21\% і 2,28\% у сорту Зимоярка (табл. 1). Вплив забруднень із найвищою питомою активністю ${ }^{137} \mathrm{Cs}{ }^{90} \mathrm{Sr}$ у воді відвідного каналу 3 , оз. Глибоке та оз. Азбучин на кореневу меристему проростків насіння пшениці не спричинив стрімкого зростання частоти аберантних клітин. За впливу радіонуклідних забруднень води відвідного каналу 3 та оз. Глибоке частота клітин із хромосомними абераціями сорту Зимоярка становила $1,96 \%$ та $1,53 \%$, що істотно перевищує спонтанний рівень відповідно у 2,8 та 3,6 раза. Статистично вірогідного зростання частоти клітин із хромосомними абераціями в сорту Альбатрос одеський за впливу радіонуклідних забруднень зазначених водойм не виявлено, проте їх рівень в 1,9 та 2,0 раза перевищував показники контролю. Зростання в 1,6 та 2,2 раза частоти аберантних клітин у сортів Альбатрос одеський та Зимоярка за відсутності статистично достовірної різниці зі спонтанними показниками також виявлено за впливу радіонуклідних забруднень води оз. Азбучин.

Рівень цитогенетичних порушень за впливу радіонуклідів у воді р. Прип'ять (м. Чорнобиль) становив для меристематичних клітин сорту Альбатрос одеський 1,06\%, для сорту Зимоярка $1,18 \%$, перевищуючи показники спонтанних хромосомних порушень відповідно в 1,7 та 2,2 раза. Зростання частоти аберантних клітин в 1,9 та 2,1 раза $(1,22 \%$ у сорту Альбатрос одеський та $1,14 \%$ у сорту Зимоярка) виявлено також у меристемі первинних корінців, які зазнали впливу радіонуклідних забруднень води р. Брагінка. Відсутність статистично достовірної різниці між частотою аберантних клітин кореневої меристеми пшениці, яка зазнала пролонгованої дії іонізуючих випромінювань радіонуклідних забруднень водойм зони відчуження ЧАЕС (оз. Азбучин, р. Прип'ять і р. Брагінка), та контролем, вказує на наближення показників цитогенетичної активності окремих водотоків і водойм зони відчуження ЧАЕС до спонтанного рівня. Однак перевищення частоти хромосомних аберацій удвічі порівняно 3 рівнем спонтанних цитогенетичних порушень свідчить про наслідки ефекту подвоювальної дози опромінення меристематичних клітин і мутагенну небезпеку існуючих низьких потужностей радіонуклідних забруднень зазначених водних об'єктів ближньої зони відчуження ЧАЕС.

За впливу радіонуклідних забруднень донних відкладів водойм частота хромосомних аберацій у клітинах кореневої меристеми пшениці перевищувала спонтанні показники в 1,6-3,3 раза (табл. 2). Найвищу цитогенетичну активність іонізуючого випромінювання виявлено за пророщування насіння в субстраті донних відкладів відвідного каналу 2 ЧАЕС. Частота аберантних клітин становила 2,50\% у сорту Альбатрос одеський і 2,94\% у сорту Зимоярка, що істотно перевищувало показники контролю відповідно у 3,3 і 3,1 раза. Зростання рівня хромосомних аберацій у 2,12,4 раза, що статистично вірогідно перевищувало спонтанні показники, виявлено за впливу радіонуклідних забруднень донних відкладів лівого берега Прип'ятського каналу та водойми-охолоджувача ЧАЕС. Унаслідок радіаційного ураження меристематичних клітин первинних корінців пшениці сорту Зимоярка, насіння якої пророщували на субстратах донних відкладів відвідних каналів 1 i 3 , частота аберантних клітин перевищувала показники контролю в 2,2-2,3 раза, на відміну від сорту Альбатрос одеський, де зростання рівня клітин із хромосомними абераціями в $1,6-1,9$ раза перебувало за межами статистичної достовірності.

Вивчивши радіоекологічні проблеми водних екосистем зони відчуження ЧАЕС, деякі дослідники дійшли висновку, що найнижчою питомою активністю радіонуклідів характеризуються компоненти річкових екосистем, донні відклади яких зазнали природного самоочищення та за роки, що минули з часу аварії, перестали відігравати істотну роль вторинного джерела забруднення водойм (Gudkov et al., 2010). У результаті аналізу цитогенетичних порушень у клітинах різних за генотипами зразків пшениці, індукованих радіонуклідами донних відкладів правого берега Прип'ятського каналу, не встановлено статистично вірогідного зростання частоти хромосомних аберацій, однак ії рівень перевищував контрольні показники удвічі. Це можна розглядати як наслідок ефекту подвоювальної дози опромінення, що свідчить про можливу генетичну небезпеку радіаційних забруднень. 
Таблиця 1

Частота хромосомних аберацій в озимої пшениці за дії радіонуклідного забруднення водойм зони відчуження ЧАЕС

\begin{tabular}{|c|c|c|c|c|c|c|}
\hline \multirow{3}{*}{ Місце відбору зразків } & \multirow{2}{*}{$\begin{array}{c}\text { Вивчено } \\
\text { ана-телофаз мітозів, } \\
\text { шт. }\end{array}$} & \multicolumn{2}{|c|}{$\begin{array}{c}\text { Мітози з порушеннями та } \\
\text { хромосомними абераціями }\end{array}$} & \multirow{2}{*}{$\begin{array}{c}\text { Вивчено } \\
\text { ана-телофаз мітозів, } \\
\text { шт. }\end{array}$} & \multicolumn{2}{|c|}{$\begin{array}{c}\text { Мітози з порушеннями та } \\
\text { хромосомними абераціями }\end{array}$} \\
\hline & & Шт. & $\%$ & & Шт. & $\%$ \\
\hline & \multicolumn{3}{|c|}{ Альбатрос одеський } & \multicolumn{3}{|c|}{ Зимоярка } \\
\hline оз. Голосіївське (контроль) & 1277 & 8 & $0,63 \pm 0,22$ & 1088 & 6 & $0,55 \pm 0,22$ \\
\hline р. Прип’ять, м. Чорнобиль & 1230 & 13 & $1,06 \pm 0,29$ & 1103 & 13 & $1,18 \pm 0,33$ \\
\hline р. Брагінка & 1067 & 13 & $1,22 \pm 0,34$ & 1317 & 15 & $1,14 \pm 0,29$ \\
\hline Водойма-охолодник ЧАЕС & 1693 & 30 & $1,77 \pm 0,32 *$ & 1358 & 30 & $2,21 \pm 0,40^{*}$ \\
\hline Семиходський затон & 1473 & 28 & $1,90 \pm 0,36^{*}$ & 1187 & 27 & $2,28 \pm 0,43^{*}$ \\
\hline Відвідний канал 3 ЧАЕС & 1490 & 19 & $1,28 \pm 0,29$ & 1173 & 23 & $1,96 \pm 0,41^{*}$ \\
\hline оз. Глибоке & 1424 & 17 & $1,19 \pm 0,29$ & 1049 & 16 & $1,53 \pm 0,38 *$ \\
\hline Оз. Азбучиин & 1599 & 16 & $1,00 \pm 0,25$ & 1070 & 13 & $1,22 \pm 0,34$ \\
\hline
\end{tabular}

Примітка: *-P $<0,05$ порівняно 3 контролем.

Таблиця 2

Частота хромосомних аберацій в озимої пшениці за дії радіонуклідного забруднення донних відкладів водойм зони відчуження ЧАЕС

\begin{tabular}{|c|c|c|c|c|c|c|}
\hline \multirow{3}{*}{ Місце відбору зразків } & \multirow{2}{*}{$\begin{array}{c}\text { Вивчено } \\
\text { ана-телофаз } \\
\text { мітозів, шт. }\end{array}$} & \multicolumn{2}{|c|}{$\begin{array}{c}\text { Мітози з порушеннями та } \\
\text { хромосомними абераціями }\end{array}$} & \multirow{2}{*}{$\begin{array}{c}\text { Вивчено } \\
\text { ана-телофаз } \\
\text { мітозів, шт. }\end{array}$} & \multicolumn{2}{|c|}{$\begin{array}{c}\text { Мітози з порушеннями та } \\
\text { хромосомними абераціями }\end{array}$} \\
\hline & & шт. & $\%$ & & шт. & $\%$ \\
\hline & \multicolumn{3}{|c|}{ Альбатрос одеський } & \multicolumn{3}{|c|}{ Зимоярка } \\
\hline оз. Голосіївське (контроль) & 1073 & 8 & $0,75 \pm 0,26$ & 1053 & 13 & $0,95 \pm 0,30$ \\
\hline Відвідний канал 1 ЧАЕС & 1187 & 17 & $1,43 \pm 0,35$ & 1112 & 23 & $2,07 \pm 0,43^{*}$ \\
\hline Відвідний канал 2 ЧАЕС & 1242 & 31 & $2,50 \pm 0,28 *$ & 1327 & 39 & $2,94 \pm 0,46^{*}$ \\
\hline Відвідний канал 3 ЧАЕС & 1063 & 13 & $1,22 \pm 0,33$ & 1235 & 27 & $2,19 \pm 0,42 *$ \\
\hline Прип’ятський канал (правий берег) & 1453 & 22 & $1,51 \pm 0,32$ & 1051 & 20 & $1,90 \pm 0,42$ \\
\hline Прип’ятський канал (лівий берег) & 1461 & 26 & $1,78 \pm 0,35^{*}$ & 1458 & 32 & $2,20 \pm 0,38 *$ \\
\hline Водойма-охолодник ЧАЕС & 1683 & 26 & $1,54 \pm 0,30 *$ & 1448 & 33 & $2,28 \pm 0,39 *$ \\
\hline
\end{tabular}

Примітка: *-P $<0,05$ порівняно з контролем.

Контроль співвідношення хромосомних порушень різного типу важливий під час проведення радіоекологічних досліджень. Адже за відносно низького стресового впливу спочатку відбувається зміна спектра порушень мітозу, а лише потім - зростання кількості патологій (Artjuhov \& Kalaev, 2005). Спектр типів хромосомних аберацій і порушень мітозу за радіонуклідного забруднення води та донних відкладів водойм зони відчуження ЧАЕС переважно представлений ацентричними фрагментами, мостами та відстаючими хромосомами (рис. $2 a-2$ ). Рівень ацентричних фрагментів і мостів у меристематичних клітинах сорту Альбатрос одеський, викликаний радіонуклідним забрудненням водойм зони відчуження ЧАЕС, перевищував рівень контролю відповідно у 1,4-
4,4 та 1,2-2,5 раза (табл. 3). Найбільшу кількість ацентричних фрагментів, що перевищувала в 2,9 та 4,4 раза їх спонтанне індукування, виявлено за впливу радіаційних забруднень водоймиохолодника ЧАЕС і Семиходського затону (рис. 3). Кількість ацентричних фрагментів і мостів у меристематичних клітинах сорту Зимоярка, індукованих випромінюванням радіонуклідних забруднень водойм зони відчуження ЧАЕС, зростала відповідно в 1,4-2,1 та 1,7-16,9 раза. За рівнем індукування мостів (зокрема, й подвійних) у клітинах сорту Зимоярка встановлено, що найвищою мутагенною активністю характеризується радіаційне забруднення водойми-охолоджувача ЧАЕС, відвідного каналу 3 ЧАЕС, оз. Азбучин, Семиходського затону.
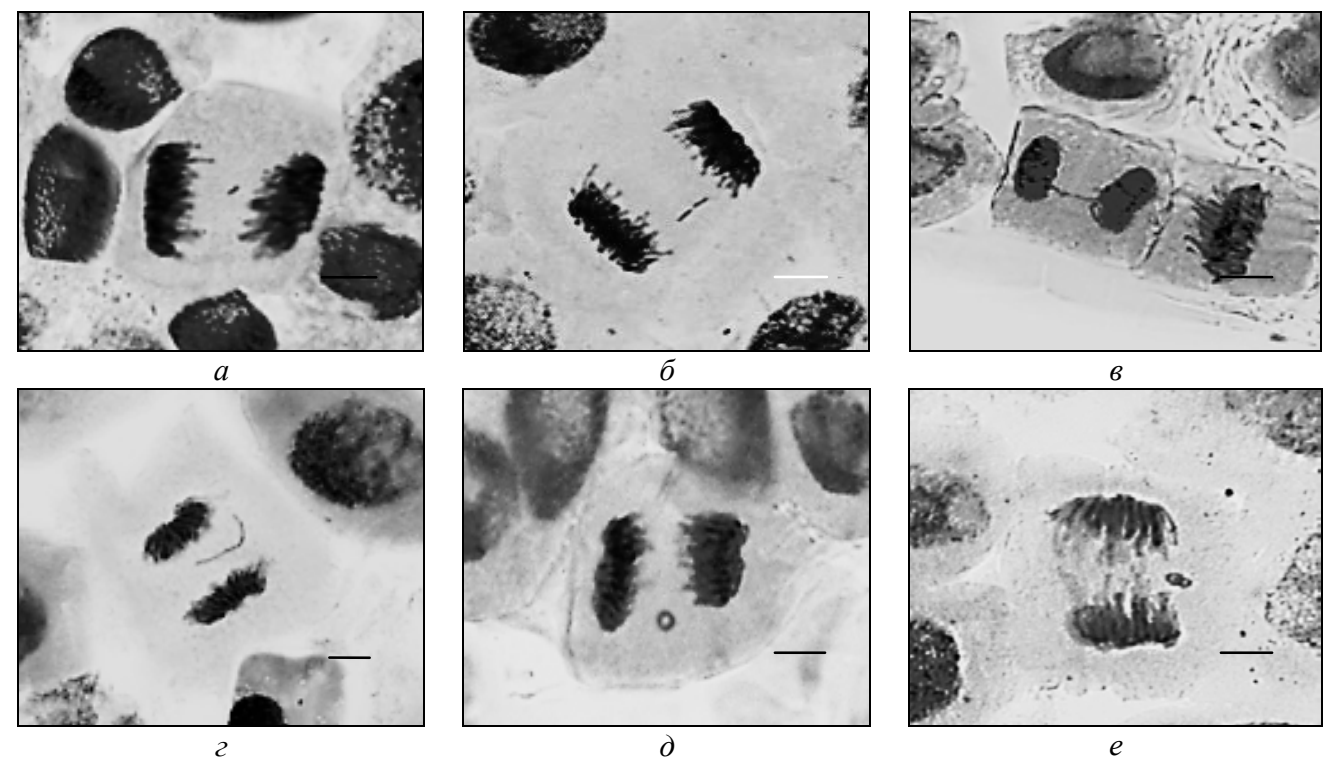

Рис. 2. Типи хромосомних аберацій і порушень мітозу, індуковані радіонуклідним забрудненням водойм зони відчуження ЧАЕС: $a$ - одиничний ацентричний фрагмент, $\sigma$ - парні ацентричні фрагменти, 6 - міст, г- відстаюча хромосома, д-хромосомне кільце, $e$ - парні хромосомні кільця; бар - 5 мкм 
Таблиця 3

Спектр типів хромосомних аберацій в озимої пшениці за дії радіонуклідного забруднення водойм зони відчуження ЧАЕС

\begin{tabular}{|c|c|c|c|c|c|c|c|}
\hline \multirow[b]{2}{*}{ Місце відбору зразків } & \multicolumn{6}{|c|}{ Частота типів порушень мітозу та хромосомних аберацій, \% } & \multirow{2}{*}{$\begin{array}{c}\text { Кількість аберацій } \\
\text { на аберантну } \\
\text { клітину } \\
\end{array}$} \\
\hline & фрагменти & мости & $\begin{array}{c}\text { фрагменти } \\
\text { та мости }\end{array}$ & мікроядра & $\begin{array}{c}\text { відстаючі } \\
\text { хромосоми }\end{array}$ & $\begin{array}{c}\text { хромосомні } \\
\text { кільця } \\
\end{array}$ & \\
\hline \multicolumn{8}{|c|}{ Альбатрос одеський } \\
\hline оз. Голосіївське (контроль) & $0,31 \pm 0,15$ & $0,24 \pm 0,14$ & 0 & 0 & $0,08 \pm 0,08$ & 0 & 1,00 \\
\hline р. Прип’ять, м. Чорнобиль & $0,57 \pm 0,21$ & $0,24 \pm 0,14$ & 0 & 0 & $0,24 \pm 0,14$ & 0 & 1,23 \\
\hline р. Брагінка & $0,66 \pm 0,25$ & $0,28 \pm 0,16$ & $0,09 \pm 0,09$ & 0 & $0,19 \pm 0,13$ & 0 & 1,15 \\
\hline Водойма-охолодник ЧАЕС & $0,89 \pm 0,23$ & $0,53 \pm 0,18$ & 0 & $0,06 \pm 0,06$ & $0,24 \pm 0,12$ & $0,06 \pm 0,06$ & $1,20 *$ \\
\hline Семиходський затон & $1,36 \pm 0,30 *$ & $0,27 \pm 0,13$ & $0,07 \pm 0,07$ & $0,07 \pm 0,07$ & $0,14 \pm 0,10$ & 0 & $1,32 *$ \\
\hline Відвідний канал 3 ЧАЕС & $0,54 \pm 0,19$ & $0,60 \pm 0,20$ & $0,07 \pm 0,07$ & $0,07 \pm 0,07$ & 0 & 0 & $1,21^{*}$ \\
\hline оз. Глибоке & $0,42 \pm 0,17$ & $0,28 \pm 0,14$ & 0 & $0,14 \pm 0,10$ & $0,35 \pm 0,15$ & 0 & 1,12 \\
\hline оз. Азбучин & $0,50 \pm 0,17$ & $0,31 \pm 0,14$ & 0 & 0 & $0,19 \pm 0,11$ & 0 & 1,19 \\
\hline \multicolumn{8}{|c|}{ Зимоярка } \\
\hline оз. Голосіївське (контроль) & $0,46 \pm 0,20$ & $0,09 \pm 0,09$ & 0 & 0 & 0 & 0 & 1,17 \\
\hline р. Прип’ять, м. Чорнобиль & $0,64 \pm 0,24$ & $0,54 \pm 0,22$ & 0 & 0 & $0,09 \pm 0,09$ & 0 & 1,31 \\
\hline р. Брагінка & $0,68 \pm 0,22$ & $0,15 \pm 0,10$ & 0 & 0 & $0,30 \pm 0,15^{*}$ & 0 & 1,13 \\
\hline Водойма-охолодник ЧАЕС & $0,96 \pm 0,26$ & $1,03 \pm 0,27 *$ & 0 & $0,07 \pm 0,07$ & $0,15 \pm 0,10$ & 0 & 1,13 \\
\hline Семиходський затон & $0,76 \pm 0,25$ & $1,52 \pm 0,35^{*}$ & 0 & 0 & 0 & 0 & 1,11 \\
\hline Відвідний канал 3 ЧАЕС & $0,85 \pm 0,27$ & $0,68 \pm 0,24 *$ & $0,09 \pm 0,09$ & 0 & $0,26 \pm 0,15$ & $0,09 \pm 0,09$ & 1,09 \\
\hline оз. Глибоке & $0,95 \pm 0,30$ & $0,19 \pm 0,13$ & 0 & 0 & $0,38 \pm 0,18^{*}$ & 0 & 1,31 \\
\hline оз. Азбучин & $0,47 \pm 0,21$ & $0,65 \pm 0,24^{*}$ & 0 & 0 & $0,09 \pm 0,09$ & 0 & 1,15 \\
\hline
\end{tabular}

Примітка: * $-\mathrm{P}<0,05$ порівняно $з$ контролем.
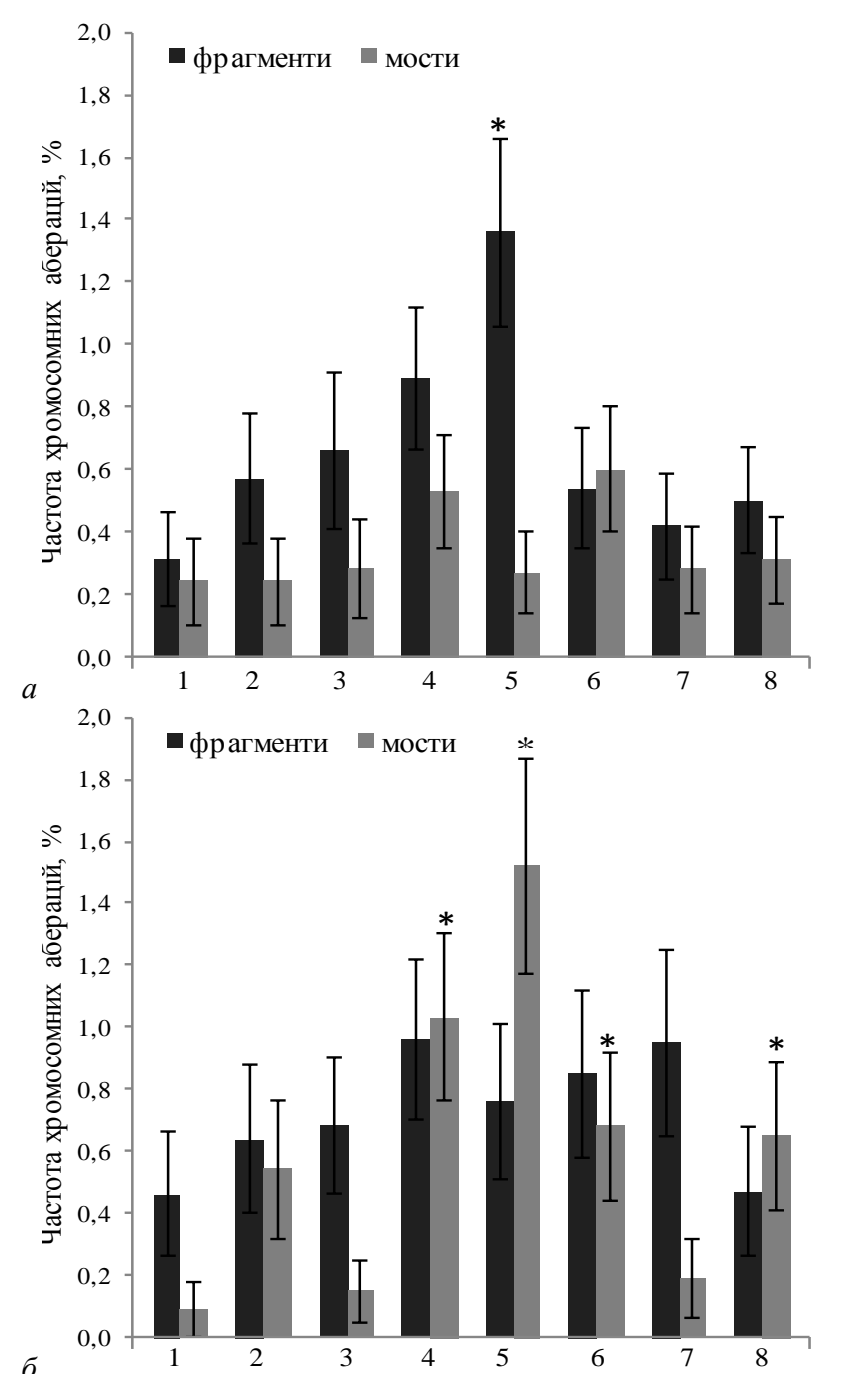

Радіонуклідне забруднення донних відкладів відвідних каналів 1, 2 та лівого берега Прип'ятського каналу спричинило зростання частоти клітин з ацентричними фрагментами в 2,5-3,9 раза, що становила 0,93\% і 1,45\% у сорту Альбатрос одеський та 0,75\% у сорту Зимоярка, за контрольних показників 0,37\% і 0,19\% (табл. 4). Істотне зростання частки мостів хромосомного та хроматидного типів відносно загального рівня цитогенетичних порушень виявлено за впливу на клітини кореневої меристеми радіонуклідних забруднень донних відкладів відвідного каналу 3 ЧАЕС і лівого берега Прип'ятського каналу у сорту Альбатрос одеський та відвідного каналу 2, правого берега Прип'ятського каналу та водойми-охолодника ЧАЕС у сорту Зимоярка (рис. 4). Їх рівень перевищував спонтанні показники у 2,2-3,1 раза і становив відповідно 0,94 і 1,16, 1,88 і 1,66\% за їх показників у контролі 0,37 i 0,76\%.

Спектр типів хромосомних аберацій у кореневій меристемі пшениці за дії радіонуклідних забруднень води та донних відкладів водойми-охолодника ЧАЕС, відвідних каналів 1-3 ЧАЕС розширювався за рахунок індукування хромосомних кілець (рис. $1 \partial, e$ ). Індукування в меристематичних клітинах проростків сорту Зимоярка парних хромосомних кілець радіонуклідними забрудненнями донних відкладів відвідного каналу 3 ЧАЕС вказує на розрив хромосоми у той момент, коли вона представлена функціонально одиничною ниткою - G0- чи G1-періоди інтерфази (Durante et al., 1998; Marković et al., 2017).

У спектрі цитогенетичних порушень, викликаних радіаційним забрудненням водойми-охолодника ЧАЕС, відвідного каналу 3 ЧАЕС і Семиходського затону, виявляються поодиноко мікроядpa, які формуються переважно з ацентричних фрагментів та чутливі до мутагенності навколишнього середовища (Osman, 2014).

Зважаючи на те, що дія іонізуючого випромінювання для природних екосистем практично ніколи не проявляється в «чистому» вигляді, орієнтація тестів із визначення цитогенетичної активності генотоксичних забруднювачів лише на облік структурних хромосомних аберацій чи пошкоджень ДНК істотно звужує уявлення про мутагенні властивості досліджуваних чинників, багато з яких здатні викликати геномні мутації без прояву вираженого кластогенного ефекту (Duesberg et al., 2000). Особливу цікавість у генетичній токсикології викликає облік нерозходження хромосом, оскільки в основі цієї події лежать первинні пошкодження не ДНК, а білків веретена поділу клітини. Найвищу частку анеуплоїдних клітин $-0,35 \%$ у сорту Альбатрос одеський виявлено за впливу радіонуклідних забруднень води оз. Глибоке та 0,38\% і 0,30\% у сорту Зимоярка - за впливу забруднень оз. Глибоке та р. Брагінка, відповідно. Значну частку цитогенетичних порушень (0,24\%) становлять відстаючі хромосоми в меристематичних клітинах сорту Альбатрос одеський, які зазнали впливу мутагенів води р. При- 
п’ять і водойми-охолодника ЧАЕС. Забруднювальні чинники донних відкладів водойм Чорнобильської зони індукують порушення мітотичного апарату з невисокою частотою 0,08-0,24\%, що дає під- ставу припустити наявність незначного вмісту анеугенів - речовин, що впливають на апарат поділу клітини, та підвищеного вмісту кластогенів - чинників, які безпосередньо діють на хромосоми.

Таблиця 4

Спектр типів хромосомних аберацій в озимої пшениці за дії радіонуклідного забруднення донних відкладів водойм зони відчуження ЧАЕС

\begin{tabular}{|c|c|c|c|c|c|c|}
\hline \multirow[b]{2}{*}{ Місце відбору зразків } & \multicolumn{5}{|c|}{ Частота типів порушень мітозу та хромосомних аберацій, \% } & \multirow{2}{*}{$\begin{array}{c}\text { Кількість аберацій } \\
\text { на аберантну } \\
\text { клітину }\end{array}$} \\
\hline & фрагменти & мости & $\begin{array}{c}\text { фрагменти і } \\
\text { мости }\end{array}$ & $\begin{array}{c}\text { відстаючі } \\
\text { хромосоми } \\
\end{array}$ & $\begin{array}{c}\text { хромосомні } \\
\text { кільця }\end{array}$ & \\
\hline \multicolumn{7}{|c|}{ Альбатрос одеський } \\
\hline оз. Голосіївське (контроль) & $0,37 \pm 0,18$ & $0,37 \pm 0,18$ & 0 & 0 & 0 & 1,00 \\
\hline Відвідний канал 1 ЧАЕС & $0,93 \pm 0,28$ & $0,42 \pm 0,19$ & 0 & 0 & $0,08 \pm 0,08$ & $1,35^{*}$ \\
\hline Відвідний канал 2 ЧАЕС & $1,45 \pm 0,34 *$ & $0,89 \pm 0,26$ & $0,08 \pm 0,08$ & $0,08 \pm 0,08$ & 0 & $1,39 *$ \\
\hline Відвідний канал 3 ЧАЕС & $0,28 \pm 0,16$ & $0,94 \pm 0,29$ & 0 & 0 & 0 & 1,08 \\
\hline Прип’ятський канал (правий берег) & $0,69 \pm 0,22$ & $0,55 \pm 0,19$ & $0,07 \pm 0,07$ & $0,20 \pm 0,12$ & 0 & $1,36^{*}$ \\
\hline Прип’ятський канал (лівий берег) & $0,48 \pm 0,18$ & $1,16 \pm 0,28^{*}$ & 0 & $0,14 \pm 0,10$ & 0 & $1,19 *$ \\
\hline Водойма-охолодник ЧАЕС & $0,71 \pm 0,20$ & $0,65 \pm 0,19$ & $0,06 \pm 0,06$ & $0,12 \pm 0,08$ & 0 & 1,12 \\
\hline \multicolumn{7}{|c|}{ Зимоярка } \\
\hline оз. Голосіївське (контроль) & $0,19 \pm 0,13$ & $0,76 \pm 0,27$ & 0 & 0 & 0 & 1,00 \\
\hline Відвідний канал 1 ЧАЕС & $0,45 \pm 0,20$ & $1,53 \pm 0,37$ & $0,09 \pm 0,09$ & 0 & 0 & $1,26^{*}$ \\
\hline Відвідний канал 2 ЧАЕС & $0,68 \pm 0,22$ & $1,88 \pm 0,37 *$ & 0 & $0,15 \pm 0,11$ & $0,15 \pm 0,11$ & $1,28^{*}$ \\
\hline Відвідний канал 3 ЧАЕС & $0,49 \pm 0,20$ & $1,38 \pm 0,33$ & 0 & $0,24 \pm 0,14$ & $0,24 \pm 0,14$ & $1,19 *$ \\
\hline Прип’ятський канал (правий берег) & $0,28 \pm 0,16$ & $1,62 \pm 0,39$ & 0 & 0 & 0 & $1,20 *$ \\
\hline Прип’ятський канал (лівий берег) & $0,75 \pm 0,22 *$ & $1,24 \pm 0,29$ & $0,07 \pm 0,07$ & $0,14 \pm 0,10$ & $0,14 \pm 0,1$ & $1,25^{*}$ \\
\hline Водойма-охолодник ЧАЕС & $0,48 \pm 0,18$ & $1,66 \pm 0,33^{*}$ & 0 & $0,07 \pm 0,07$ & $0,07 \pm 0,07$ & $1,12^{*}$ \\
\hline
\end{tabular}

Примітка: $*-\mathrm{P}<0,05$ порівняно $з$ контролем.

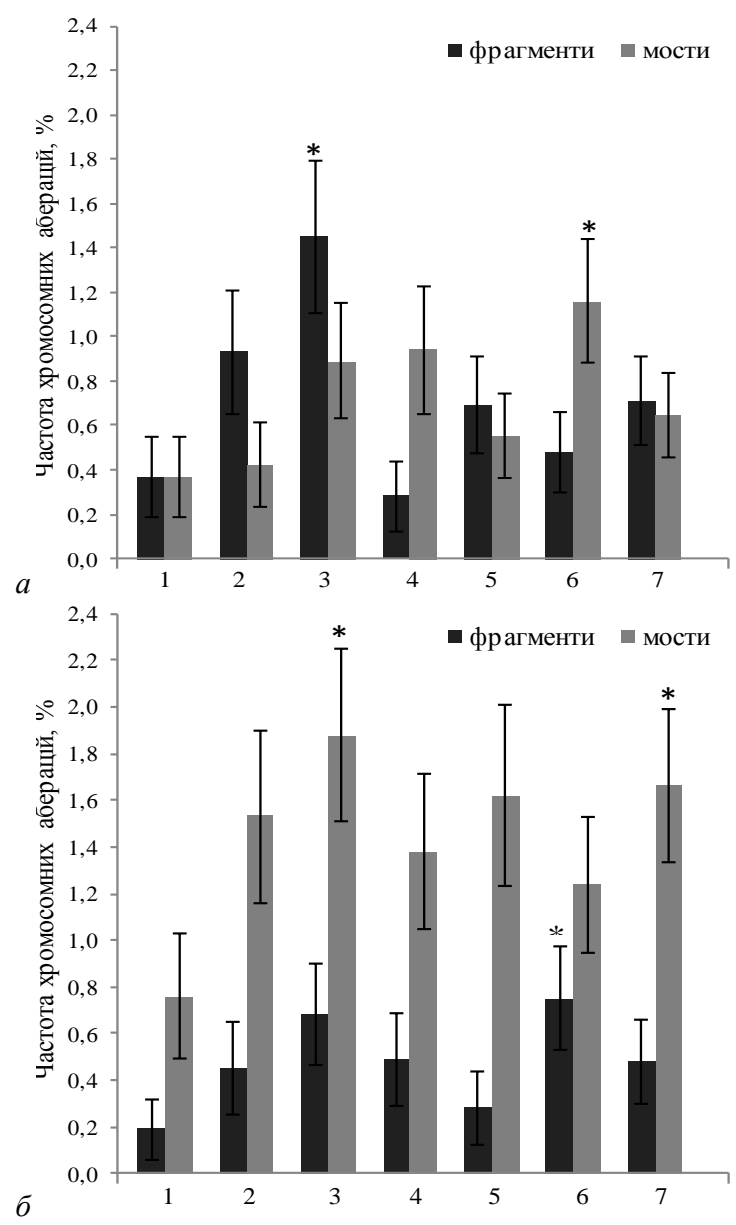

Рис. 4. Індукування в озимої пшениці сортів Альбатрос одеський (a) та Зимоярка (б) ацентричних фрагментів і мостів радіонуклідними забрудненнями донних відкладів водойм зони відчуження ЧАЕС: 1 - оз. Голосіївське (контроль), 2 - відвідний канал 1 ЧАЕС, 3 - відвідний канал 2 ЧАЕС, 4 - відвідний канал 3 ЧАЕС, 5-Прип'ятський канал (правий берег), 6-Прип'ятський канал (лівий берег), 7 - водойма-охолодник ЧАЕС; *_ $\mathrm{P}<0,05$ порівняно $з$ контролем; $\mathrm{n}=1$ 000, $\mathrm{x} \pm \mathrm{SE}$
Тяжкість генетичних порушень, спричинених радіаційним опроміненням, відображають клітини 3 множинними абераціями. Показник кількості аберацій на аберантну клітину не перебуває у прямій залежності від частоти аберантних клітин і являє собою якісно відмінну кількісну характеристику цитогенетичної активності радіаційного забруднення середовища (Tawn et al., 2017). Установлено, що кількість аберацій на аберантну клітину для сорту Альбатрос одеський найвищий за впливу забруднень води Семиходського затону $(1,32)$, р. Прип'ять $(1,23)$, водойми-охолоджувача ЧАЕС $(1,20)$ та відвідного каналу 3 ЧАЕС $(1,21)$, а для сорту Зимоярка - за впливу забруднень води р. Прип'ять та оз. Глибоке (1,31). Незважаючи на невисоку частоту клітин із хромосомними абераціями, питома активність радіонуклідів у воді р. Прип'ять індукує в меристемі проростків пшениці зростання частки клітин із множинними абераціями. В меристемі проростків за дії радіонуклідних забруднень донних відкладів відвідних каналів 1 і 2 ЧАЕС та лівого та правого берегів Прип'ятського каналу показник кількості аберацій на аберантну клітину становить 1,08-1,39 у сорту Альбатрос одеський та 1,12-1,26 - у сорту Зимоярка. Радіонуклідне забруднення донних відкладів правого берега Прип'ятського каналу, яке індукує низьку частоту клітин із хромосомними абераціями, викликає в меристемі проростків пшениці істотне зростання частки клітин із множинними абераціями. Отже, природні водні об'єкти зони відчуження ЧАЕС, рівень радіонуклідних забруднень яких характеризується високою цитогенетичною активністю, індукують із високою частотою клітини з комплексними хромосомними перебудовами, що вважається специфічним проявом біологічного впливу іонізуючого випромінювання.

\section{Обговорення}

За останні роки у грунтах Чорнобильської зони відчуження встановлено тенденцію до збільшення виходу мобільних біологічно доступних форм радіонуклідів, які з поверхневими та грунтовими водами потрапляють у гідрологічну мережу, де швидко включаються у біотичний кругообіг (Gudkov et al., 2010; Gudkov et al., 2016). Донині не втрачає своєї актуальності оцінювання мутагенної активності головного джерела надходження радіонуклідів до каскаду дніпровських водойм - p. Прип'ять із численними озерами та старицями іï заплави, які у післяаварійний період зазнали найінтенсивнішого радіонуклідного забруднення (Gudkov et al., 2010; Bird \& Little, 2013; Suga et al., 2014; Fuller et al., 2018). Збіль- 
шення кількості аберацій хромосом у клітинах меристематичних тканин - неспецифічна реакція клітин живих організмів на вплив мутагенів навколишнього середовища, яка виявляється за дії чинників різної природи, зокрема іонізуючої радіації (Pojoga et al., 2013; Tawn et al., 2015; Nurmansyah et al., 2018). На відміну від природного радіаційного фону, додаткове опромінення від штучних радіонуклідів у замкнених і проточних водоймах зони відчуження, що характеризується значною неоднорідністю розподілу у просторі та часі, спричиняють непрогнозоване багаторазове зростання частоти хромосомних аберацій у рослин мікроядер у клітинах крові гідробіонтів тваринного походження, появу флуктуаційної асиметрії молюсків, потворностей і канцерогенезу риб (Gudkov et al., 2011; Rudenko et al., 2013; Gudkov et al., 2016a, 2016b).

Радіонуклідне забруднення водойм ближньої зони відчуження ЧАЕС через 30 років після аварії продовжує зберігати високу цитогенетичну активність та індукує в клітинах кореневої меристеми озимої пшениці істотне зростання цитогенетичних порушень. Рівень аберантних клітин кореневої меристеми T. aestivum L. не перебуває у прямій залежності від сумарної питомої активності ${ }^{137} \mathrm{Cs} \mathrm{i}{ }^{90} \mathrm{Sr}$ у воді та субстратах донних відкладів водойм, що може бути зумовлено особливістю механізмів репарації пошкоджень ДНК у діапазоні низьких доз опромінення. Складну нелінійну залежність «доза - ефект» у районі низьких доз виявили також інші дослідники за хронічного опромінення в зонах відчуження ЧАЕС та Східно-Уральського радіаційного сліду в Crepis tectorum L., Hordeum vulgare L. лініï waxy, Rana temporaria L., Clethrionomys glareolus L., Cricetulus griseus L., клітин людини (Shevchenko et al., 1998; Shmakova et al., 2002; Geras'kin et al., 2007). Відсутність залежності виходу генетичних порушень від дози опромінення пов'язують 3 увімкненням за певних умов ушкодження клітин індуцибельної репарації та цитопротекторних процесів, що підвищують радіорезистентність клітинної популяції (Janion, 2008).

В інших дослідженнях виявлено залежність частоти хромосомних порушень від величини питомої активності забруднення ${ }^{137} \mathrm{Cs}$ води та грунту у Phragmites australis L., Lymnaea stagnalis L., Pinus sylvestris L., Oenothera biennis L., які зазнавали хронічного впливу високих потужностей як зовнішнього, так і внутрішнього іонізуючого опромінення (Ramzaev et al., 2008; Geras’kin \& Volkova, 2014; Gudkov et al., 2016). Відповідно реальне дозове навантаження на клітини меристеми може на порядок перевищувати оцінки доз, розрахованих із припущення рівномірного опромінення тканин рослин (Gudkov et al., 2011; Geras’kin \& Volkova, 2014).

Біологічні маркери радіаційного ураження організмів - парні ацентричні фрагменти та дицентричні хромосоми, які виявились переважаючими типами хромосомних аберацій за обробки насіння пробами води та донних відкладів водойм ближньої зони ЧАЕС. Існує точка зору, що підвищений рівень ацентричних фрагментів - ознака пролонгованого опромінення низької потужності. Радіаційно-індуковані в $\mathrm{G}_{2}$-періоді розриви хроматид утворюються в момент конденсації хроматину та формування хроматинового волокна (Parshad \& Sanford, 2001; Magin et al., 2015; Guogyte et al., 2017). Мости з'являються як у результаті розриву та об'єднання розірваних кінців хромосом, так і внаслідок аглютинації (злипання хромосом) (Muratova et al., 2014; Albertson, 2015; Zotina et al., 2015; Pampalona et al., 2016). У працях інших дослідників також зазначається причетність районів із радіоактивним забрудненням до утворення подвійних і множинних дицентриків (Geras’kin et al., 2011; Firbas \& Amon, 2014). Не менш важливі маркери радіаційного впливу - хромосомні кільця (Geras'kin et al., 2011; Hristova et al., 2013; Firbas \& Amon, 2014; Medvedeva et al., 2014), які виявлено за дії радіонуклідних забруднень води та донних відкладів водойми-охолоджувача і відвідних каналів 1-3 ЧАЕС. Вважається, що їх утворення пов'язане $з$ обміном ділянками двох плечей тієї самої хромосоми зі злиттям їі проксимальних кінців (Medvedeva et al., 2014). Розрив хромосом і утворення мостів супроводжуються появою ацентричних фрагментів, які найчастіше запізнюються в мітозі. За радіаційного впливу формування мікроядер на 90\% пов'язане з включенням таких фрагментів (Lisowska et al., 2014; Qian et al., 2016). Тому їх поява з частотою 0,07-0,14\% за впливу радіонуклідних забруднень водойми-охолодника ЧАЕС відвідного каналу 3 ЧАЕС, Семиходського затону і оз. Глибоке свідчить про радіаційне ураження меристематичних клітин.

Спектр цитогенетичних порушень розширювався також за рахунок індукування клітин із відстаючими хромосомами. Це може бути пов'язано з наявністю у водоймах хімічних ксенобіотиків i важких металів, які у великих кількостях використовували для дезактивації найзабрудненіших радіонуклідами територій зони відчуження ЧАЕС. Ефект їх впливу частіше проявляється через взаємодію з багатьма мішенями, що прямо чи опосередковано контролюють сегрегацію хромосом. Наслідок таких подій - нелінійна залежність частоти кількісних хромосомних порушень від концентрації мутагену (Elhajouji et al., 2011). Поява клітин із відстаючими хромосомами може бути пов'язана з порушенням організації клітинних центрів поділу, дефектами веретена поділу, пошкодженнями кінетохору чи його функції, змінами відносин між веретеном поділу та кінетохорами, дефектами центромерного району, змінами взаємодій між центромерними районами сестринських хроматид у процесі мітозу (Compton, 2011; Passerini et al., 2016). Виявлений тип порушень хромосомного апарату, за даними деяких авторів (Kovaleva \& Bagatskaia, 2013), дуже рідко зустрічається в популяціях, не обтяжених дією мутагенних факторів, що свідчить про порушення процесів клітинного поділу в результаті нерозходження хромосом у разі блокади веретена поділу.

Природні водні об'єкти зони відчуження ЧАЕС, рівень радіонуклідних забруднень яких характеризується високою цитогенетичною активністю, індукують клітини 3 комплексними хромосомними перебудовами, що вважається специфічним проявом біологічного впливу іонізуючого випромінювання. Індуковані радіаційним опроміненням первинні пошкодження молекул ДНК розподілені по клітинах відповідно до закону Пуассона (Obe et al., 2002), а їх кінцевий розподіл може істотно від цього відрізнятися. Більше того, чим значніша роль систем відновлення, тим більше розподіл пошкоджень має відрізнятися від пуассонівського. Відомо, що кількість клітин із множинними абераціями дозозалежно збілышується лише в умовах значного мутагенного навантаження (Shkarupa et al., 2011), тому зростання показника кількості аберацій на аберантну клітину за впливу забруднень водойм штучними радіонуклідами свідчить про їх високу мутагенну активність, яка частково визначається особливістю реакції-відповіді системи відновлення ДНК радіаційно ураженої клітини в діапазоні малих доз (Borrego-Soto et al., 2015; McMahon et al., 2016). Таке припущення знаходить своє підтвердження під час аналізу експериментальних даних щодо розподілу структурних мутацій по клітинах за опромінення насіння та проростків багатьох інших сільськогосподарських рослин (Geras’kin et al., 2007).

\section{Висновки}

Радіонуклідне забруднення водойм ближньої зони відчуження ЧАЕС через 30 років після аварії продовжує зберігати високу цитогенетичну активність та індукує у клітинах кореневої меристеми озимої пшениці істотне зростання цитогенетичних порушень, що в 1,6-4,2 раза перевищує спонтанний рівень. За показниками частоти аберантних клітин, спектра типів хромосомних аберацій та кількості аберацій на аберантну клітину вона найвища для радіонуклідних забруднень води Семиходського затону, відвідного каналу 3 ЧАЕС, оз. Глибоке, донних відкладів відвідного каналу 2 ЧАЕС, лівого берега Прип'ятського каналу, води та донних відкладів водойми-охолодника ЧАЕС. Залежності між рівнем хромосомних аберацій і величиною питомої активності радіонуклідів водойм не виявлено, що може свідчити про індукування цитогенетичних порушень у клітинах кореневої меристеми пшениці внаслідок опромінення в діапазоні низьких доз.

Незважаючи на відсутність істотної різниці між спонтанною частотою аберантних клітин та індукованою радіонуклідним забрудненням води р. Прип'ять поблизу м. Чорнобиль, р. Брагінка та донних відкладів правого берега Прип'ятського каналу, підвищений рівень анеугенних клітин та виявлення клітин із множин- 
ними хромосомними абераціями свідчить про генетичну небезпеку для організмів зазначених водних об'єктів. 3 огляду на те, що питома радіоактивність водойм і водотоків нині визначається інтенсивністю переходу депонованих донними відкладами радіонуклідів у водні маси, під час виведення з експлуатації водоймиохолоджувача ЧАЕС та зміни рівня води у водоймах ближньої зони відчуження необхідно передбачити серед критичних подій можливість зростання мутагенної активності забруднень водних екосистем і важких генетичних наслідків у гідробіонтів.

\section{References}

Albertson, D. G. (2015). Molecular genetics methods in discovery of chromosome structure. Chromosomal Translocations and Genome Rearrangements in Cancer, New York University College of Dentistry, New York, pp. 15-25.

Al-Dulaimi, D. W., Faisal, S. F., Baharetha, H. M., \& Majid, A. M. S. A. (2017). Cytogenetic an experimental monitoring test for plant extracts. Journal of Pharmacy and Biological Sciences, 12(3), 100-105.

Artjuhov, V. G., \& Kalaev, V. N. (2005). Citogeneticheskie pokazateli semennogo potomstva derev'ev duba chereshchatogo (Quercus robur L.), podvergshihsja vozdejstviju radioaktivnosti v rezul'tate avarii na Chemobyl'skoj AES i proizrastajushhih na territorijah s raznym urovnem antropogennogo zagrjaznenija [Cytogenetic indicators of seed progeny of Quercus robur L. trees exposed to radioactivity as a result of the Chernobyl accident and growing in areas with different levels of anthropogenic pollution]. Radiation Biology. Radioecology, 45(5), 619-628 (in Russian).

Ashraf, M. A., Akib, S., Maah, M. J., Yusoff, I., \& Balkhair, K. S. (2014). Cesium137: Radio-chemistry, fate, and transport, remediation, and future concerns. Critical Reviews in Environmental Science and Technology, 44, 1740-1793.

Beresford, N. A., Fesenko, S., Konoplev, A., Skuterud, L., Smith, J. T., \& Voigt, G. (2016). Thirty years after the Chernobyl accident: What lessons have we learnt? Journal of Environmental Radioactivity, 157, 77-89.

Bird, W. A., \& Little, J. B. (2013). A tale of two forests: Addressing postnuclear radiation at Chernobyl and Fukushima. Environmental Health Perspectives, 121(3), 78-85.

Bondar, Y. I., Nenashev, R. A., Kalinichenko, S. A., Marchenko, Y. D., Dowdall, M., Standring, W., Brown, J. E., Pettersen, M., Skipperud, L., \& Zabrotski, V. N. (2015). The distribution of ${ }^{137} \mathrm{Cs},{ }^{90} \mathrm{Sr}$, and ${ }^{241} \mathrm{Am}$ in waterbodies of different origins in the Belarusian part of Chemobyl exclusion zone. Water, Air, and Soil Pollution, 226(3), 1-13.

Bondarkov, M. D., Oskolkov, B. Y., Gaschak, S. P., Kireev, S. I., Maksimenko, A. M., Proskura, N. I., Jannik, G. T., \& Farfán, E. B. (2011). Environmental radiation monitoring in the Chernobyl exclusion zone - history and results 25 years after. Health Physics, 101(4), 442-485.

Borrego-Soto, G., Ortiz-López, R., \& Rojas-Martínez, A. (2015). Ionizing radiateon-induced DNA injury and damage detection in patients with breast cancer. Genetics and Molecular Biology, 38(4), 420-432.

Boubriak, I., Akimkina, T., Polischuk, V., Dmitriev, A., McCready, S., \& Grodzinsky, D. (2016). Long term effects of Chemobyl contamination on DNA repair function and plant resistance to different biotic and abiotic stress factors. Cytology and Genetics, 50(6), 381-399.

Busby, C. (2017). Radiochemical genotoxicity risk and absorbed dose. Research and Reports on Toxicology, 1(1), 1-13.

Compton, D. A. (2011). Mechanisms of Aneuploidy. Current Opinion in Cell Biology, 23(1), 109-113.

Duesberg P., Li, R., \& Rasnick, D. (2000). Aneuploidy precedes and segregates with chemical carcinogenesis. Cancer Genetics and Cytogenetics, 119, 83-93.

Durante, M., Furusawa, Y., \& George, K. (1998). Rejoining and misrejoining of radiation-induced chromatin breaks. Radiation Research, 149, 446-454.

Elhajouji, A., Lukamowicz, M., Cammerer, Z., \& Kirsch-Volders, M. (2011). Potential thresholds for genotoxic effects by micronucleus scoring. Mutagenesis, 26(1), 199-204.

Evangeliou, N., Balkanski, Y., Cozic, A., Hao, W. M., Mouillot, F., Thonicke, K., Paugam, R., Zibtsev, S., Mousseau, T. A., Wang, R., Poulter, B., Petkov, A. Yue, C., Cadule, P., Koffi, B., Kaiser, J. W., \& Møller, A. P. (2015). Fire evolution in the radioactive forests of Ukraine and Belarus: Future risks for the population and the environment. Ecological Monographs, 85(1), 49-72.

Evangeliou, N., Hamburger, T., Talerko, N., Zibtsev, S., Bondar, Y., Stohl, A., Balkanski, Y., Mousseau, T. A., \& Møller, A. P. (2016). Reconstructing the Chernobyl Nuclear Power Plant (CNPP) accident 30 years after. A unique database of air concentration and de position measurements over Europe. Environmental Pollution, 216, 408-418.

Firbas, P., \& Amon, T. (2014). Chromosome damage studies in the onion plant Allium cepa L. International Journal of Cytology, Cytosystematics and Cytogenetics, 67(1), 25-35.
Fuller, N., Ford, A. T., Nagorskaya, L. L., Gudkov, D. I., \& Smith, J. T. (2018). Reproduction in the freshwater crustacean Asellusa quaticus along a gradient of radionuclide contamination at Chernobyl. Science of the Total Environment, 628-629, 11-17.

Fuller, N., Lerebours, A., Smith, J. T., \& Ford, A. T. (2015). The biological effects of ionising radiation on Crustaceans: A review. Aquatic Toxicology, 167, 55-67.

Garnier-Laplace, J., Beaugelin-Seiller, K., Della-Vedova, C., Métivier, J.-M., Ritz, C., Mousseau, T. A., \& Møller, A. P. (2015). Radiological dose reconstructtion for birds reconciles outcomes of Fukushima with knowledge of doseeffect relationships. Scientific Reports, 5, 1-13.

Geras'kin, S. A., \& Volkova, P. Y. (2014) Genetic diversity in Scots pine populations along a radiation exposure gradient. Science of the Total Environment, 496, 317-327.

Geras'kin, S. A., Oudalova, A. A., Kim, J. K., Dikarev, V. G., \& Dikareva, N. S. (2007). Cytogenetic effect of low dose gamma-radiation in Hordeum vulgare seedlings: Non-linear dose-effect relationship. Radiation and Environmental Biophysics, 46(1), 31-41.

Geras'kin, S., Oudalova, A. A., Docareva, N. S., Spiridonov, S., Hinton, T., Chernonog, E., \& Garnier-Laplace, J. (2011). Effects of radioactive contamination on Scots pines in the remote period after the Chernobyl accident. Ecotoxicology, 20, 1195-1208.

Gudkov, D. I., Kuzmenko, M. I., Kireev, S. I., Nazarov, A. B., Shevtsova, N. L., Dziubenko, E. V., \& Kaglian, A. E. (2010). Radioecological problems of aquatic ecosystems of the Chernobyl exclusion zone. Biophysics, 55(2), 332-339.

Gudkov, D. I., Shevtsova, N. L., Pomortseva, N. A., Dzyubenko, E. V., Kaglyan, A. E., \& Nazarov, A. B. (2016a). Radiation-induced cytogenetic and hematologic effects on aquatic biota within the Chernobyl exclusion zone. Journal of Environmental Radioactivity, 151(2), 438-448.

Gudkov, D., Dzyubenko, E., Shevtsova, N. M., \& Nazarov, A. (2011). Aquatic biota within the Chernobyl accident exclusion zone: Consequences of the long-term radiation exposure. Radiobiology and Environmental Security, 116, 233-244.

Gudkov, D., Dzyubenko, Y. V., Nazarov, A. B., \& Klenus, V. G. (2016). Freshwater mollusks in the exclusion zone of the Chernobyl NPS: Dynamics of radionuclide content, dose loads, and cytogenetic and hematological investigations. Hydrobiological Journal, 46(5), 74-90.

Guogytė, K., Plieskienė, A., Ladygienė, R., Vaisiūnas, Ž., Sevriukova, O., Janušonis, V., \& Žiliukas, J. (2017). Assessment of correlation between chromosomal radiosensitivity of peripheral blood lymphocytes after in vitro irradiation and normal tissue side effects for cancer patients undergoing radiotherapy. Genome Integrity, 8(1).

Hristova, R., Hadjidekova, V., Grigorova, M., Nikolova, T., Bulanova, M., Popova, L., Staynova, A., \& Benova, D. (2013). Chromosome analysis of nuclear power plant workers using fluorescence in situ hybridization and Giemsa assay. Journal of Radiation Research, 54(5), 832-839.

Itoh, M., Kajihara, R., Kato, Y., Takano-Shimizu, T., \& Inoue, Y. (2018). Frequencies of chromosomal inversions in Drosophila melanogaster in Fukushima after the nuclear power plant accident. PLoS One, 13(2), 0192096.

Janion, C. (2008). Inducible SOS response system of DNA repair and mutagenesis in Escherichia coli. International Journal of Biological Sciences, 4(6), 338-344.

Konoplev, A., Golosov, V., Laptev, G., Nanba, K., Onda, Y., Takase, T., Wakiyama, Y., \& Yoshimura, K. (2016). Behavior of accidentally released radiocesium in soil-water environment: Looking at Fukushima from a Chemobyl perspective. Journal of Environmental Radioactivity, 151, 568-578.

Kosakovskaja, I. V., \& Gudkova, N. V. (2005). Vlijanie gamma-radiacii i vysokoj temperatury na sostav kislotorastvorimyh jadernih belkov prorostkov ozimoj pshenicy [Effect of gamma radiation and high temperature on the composition of acid-soluble nuclear proteins of winter wheat seedlings]. Physiology and Biochemistry of Cultivated plants, 37(1), 24-29 (in Russian).

Kovaleva, V. I., \& Bagatskaia, N. V. (2013). Cytogenetic effects in peripheral blood lymphocytes in the offspring of Chernobyl nuclear power plant accident liquidators under the influence of mitomycin $\mathrm{C}$ in vitro and folic acid in vivo. Cytology and Genetics, 47(1), 68-73.

Lisowska, H., Brehwens, K., Zölzer, F., Wegierek-Ciuk, A., Czub, J., \& Lankoff, A. (2014). Effect of hypothermia on radiation-induced micronuclei and delay of cell cycle progression in TK6 cells. International Journal of Radiation Biology, 90(4), 318-324.

Magin, S., Papaioannou, M., Saha, J., Staudt, C., \& Iliakis, G. (2015). Inhibition of homologous recombination and promotion of mutagenic repair of DNA double-strand breaks underpins arabinoside-nucleoside analogue radiosensitization. Cancer Biology and Signal Transduction, (3), 1424-1433.

Marković, S. Z., Nikolić, L. I., Hamidović, J. L., Grubor, M. G., Grubor, M. M., \& Kastratović, D. A. (2017). Chromosomes aberations and enviromental factors. Hospital Pharmacology, 4(1), 486-490.

McMahon, S. J., Schuemann, J., Paganetti, H., \& Prise, K. M. (2016). Mechanistic modelling of DNA repair and cellular survival following radiation-induced DNA damage. Scientific Reports, 7, 1-14. 
Medvedeva, M. Y., Bolsunovsky, A. Y., \& Zotina, T. A. (2014). Cytogenetic abnormalities in aquatic plant Elodea canadensis in anthropogenic contamination zone of Yenisei River. Contemporary Problems of Ecology, 7(4), 422-432.

Mousseau, T. A., \& Møller, A. P. (2014). Genetic and ecological studies of animals in Chemobyl and Fukushima. Journal of Heredity, 105(5), 704-709.

Muratova, E. N., Goryachkina, O. V., Kornilova, M. G., Pimenov, A. V., Sedelnikova, T. S., \& Bolsunovsky, A. Y. (2014). Cytogenetic studies on submerged plants from the Yenisei river area in the zone of radioactive contamination. Biology Bulletin, 41(5), 461-467.

Nakamura, N. (2018). Why genetic effects of radiation are observed in mice but not in humans. Radiation Research, 189, 117-127.

Nurmansyah, Y., Alghamdi, S. S., Migdadi, H. M., \& Farooq, M. (2018). Morphological and chromosomal abnormalities in gamma radiation-induced mutagenized faba bean genotypes. Intemational Journal of Radiation Biology, 94(2), 174-185.

Obe, G., Pfeiffer, P., Savage, J. R. K., Johannes, C., Goedecke, W., Jeppesen, P., Natarajan, A. T., Martinez-López, W., Folle, G. A., \& Drets, M. E. (2002). Chromosomal aberrations: Formation, identification and distribution. Mutation Research, 504, 17-36.

Osman, A. G. M. (2014). Genotoxicity tests and their contributions in aquatic environmental research. Journal of Environmental Protection, 5, 1391-1399.

Pampalona, J., Roscioli, E., Silkworth, W. T., Bowden, B., Genescà, A., Tusell, L., \& Cimini, D. (2016). Chromosome bridges maintain kinetochore-microtubule attachment throughout mitosis and rarely break during anaphase. PLoS One, 11(1), 0147420.

Parshad, R., \& Sanford, K. K. (2001). Radiation-induced chromatid breaks and deficient DNA repair in cancer predisposition. Hematology, 37, 87-96.

Passerini, V., Ozeri-Galai, E., de Pagter, M. S., Donnelly, N., Schmalbrock, S., Kloosterman, W. P., Kerem, B., \& Storchova, Z. (2016). The presence of extra chromosomes leads to genomic instability. Nature Communications, 7, 10754.

Pausheva, Z. P. (1988). Praktikum po citologii rastenij [Workshop on plant cytology]. Agropromizdat, Moscow (in Russian).

Pohrebennyk, V., Politylo, R., Yakovleva, V., \& Salamon, I. (2016). Radioecological monitoring of groundwater resources in the Chernobyl exclusion zone. Journal of Acta Facultatis Studiorum Humanitatis et Naturae Universitatis Prešoviensis, 43, 136-142.

Pojoga (Usurelu), M. D., Manaila, E., Nicoleta, C., Duta, C. G., Cimponeriu, D., \& Simon-Gruita A. (2013). Chromosome aberrations, telomere and telomerase dysfunction after beta irradiation in human lymphocytes. Romanian Biotechnological Letters, 18(5), 8603-8612.

Qian, Q. Z., Cao, X. K., Shen, F. H., \& Wang, Q. (2016). Effects of ionising radiation on micronucleus formation and chromosomal aberrations in Chinese radiation workers. Radiation Protection Dosimetry, 168(2), 197-203.

Qureshi, S. T., Memon, S. A., Abassi, A. R., Sial, M. A., \& Bughio, F. A. (2017) Radiofrequency radiations induced genotoxic and carcinogenic effects on chickpea (Cicer arietinum L.) root tip cells. Saudi Journal of Biological Sciences, 24(4), 883-891.

Ramzaev, V., Bøtter-Jensen, L., \& Thomsen, K. J. (2008). An assessment of cumulative external doses from Chernobyl fallout for a forested area in Russia using the optically stimulated luminescence from quartz inclusions in bricks. Journal of Environmental Radioactivity, 99(7), 1154-1164.
Romanenko, V., Gudkov, D., \& Kuz'menko, M. (2014). Gidrobionty vodojm Chomobyl's'koi' zony [Hydrobionts of reservoirs of the Chernobyl zone]. Svitogljad, 46(2), 37-46 (in Ukrainian).

Rudenko, L. I., Han, V. E., Odincov, A. A., \& Dzhuzha, O. V. (2013). Fazovoe raspredelenie, formy nahozhdenija i dolja mikrochastic v gruntovoj vode po ${ }^{137} \mathrm{Cs},{ }^{90} \mathrm{Sr}$, uranu i transuranovym jelementam [The phase distribution, the forms of occurrence and the fraction of microparticles in groundwater over ${ }^{137} \mathrm{Cs},{ }^{90} \mathrm{Sr}$, uranium and transuranium elements]. Reports of the National Academy of Sciences of Ukraine, 7, 165-171 (in Russian).

Sazykina, T. G., \& Kryshev, A. I. (2003). EPIC database on the effects of chronic radiation in fish. Journal of Environmental Radioactivity, 68, 65-87.

Shevchenko, V. V., Grinih, L. I., \& Abramov, V. I. (1998). Citogeneticheskie effekty v prirodnyh populjacijah Crepis tectorum L., proizrastajushhih v rajone Vostochno-Ural'skogo radioaktivnogo sleda [Cytogenetic effects in natural populations of Crepis tectorum L., growing in the area of the East Urals radioactive trace]. Radiation Biology. Radioecology, 38(3), 330-336 (in Russian).

Shkarupa, V. M., Neumerzhic'ka, L. V., Klimenko, S. V., \& Simiglazova, T. V. (2011) Dynamika zmin spektra aberacij hromosom, indukovanyh mitomicynom C u Allium cepa L. [Dynamics of changes in spectrum of aberrations of chromosomes induced by mitomycin C in Allium cepa L.]. Bulletin of the Ukrainian Society of Genetics and Breeders, 9(1), 112-117.

Shmakova, N. L., Fadeeva, T. A., \& Nasonova, E. A. (2002). Citogeneticheskie jeffekty malyh doz obluchenija v kletkah mlekopitajushhih: Analiz fenomena giperchuvstvitel'nosti i inducirovannoj rezistentnosti [Cytogenetic effects of small doses of irradiation in mammalian cells: An analysis of the phenomenon of hypersensitivity and induced resistance]. Radiation Biology, Radioecology, 42(3), 245-250 (in Russian).

Shuryak, I. (2017). Quantitative modeling of responses to chronic ionizing radiation exposure using targeted and non-targeted effects. PLoS One, 12(4), 0176476.

Suga, H., Fan, Q., Takeichi, Y., Tanaka, K., Kondo, H., Kanivets, V. V., Sakaguchi, A., Kato, K., Inami, N., Mase, K., Ono, K., \& Takahashi, Y. (2014). Characterization of particulate matters in the Pripyat River in Chernobyl related to their adsorption of radiocesium with inhibition effect by natural organic matter. Chemistry Letters, 43(7), 1128-1130.

Talerko, N. N., Garger, E. K., \& Kuz'menko, A. G. (2013). Prognoznaja ocenka transgranichnogo perenosa radionuklidov vsledstvie prohozhdenija smercha nad vodoemom-ohladitelem ChAJeS [Predictive assessment of cross-border transport of radionuclides due to the passage of the tornado cooling pond Chernobyl]. Problems of Safety of Nuclear Power Plants and Chernobyl, 20, 85-93 (in Ukrainian).

Tawn, E. J., Curwen, G. B., Jonas, P., Gillies, M., Hodgson, L., \& Cadwell, K. K. (2015). Chromosome aberrations determined by FISH in radiation workers from the Sellafield nuclear facility. Radiation Research, 184(3), 296-303.

Tawn, E. J., Curwen, G. B., Riddell, A. E., Lioyd, D. C., \& Ainsbury, E. A (2017). Chromosome analysis in a case of a plutonium contaminated wound. Journal of Radiological Protection, 37(2), 13-18.

Topashka-Ancheva, M., \& Gerasimova, T. (2012) Genomic sensitivity of small Mammals - a suitable test system in the genetic monitoring. In: Begum, G. (ed.). Ecotoxicology. InTech, Rijeka. Pp. 125-146.

Zotina, T. A., Trofimova, E. A., Medvedeva, M. Y., Dementyev, D. V., \& Bolsunovsky, A. Y. (2015). Use of the aquatic plant Elodea canadensis to assess toxicity and genotoxicity of Yenisei river sediments. Environmental Toxicology and Chemistry, 34(10), 2310-2321. 